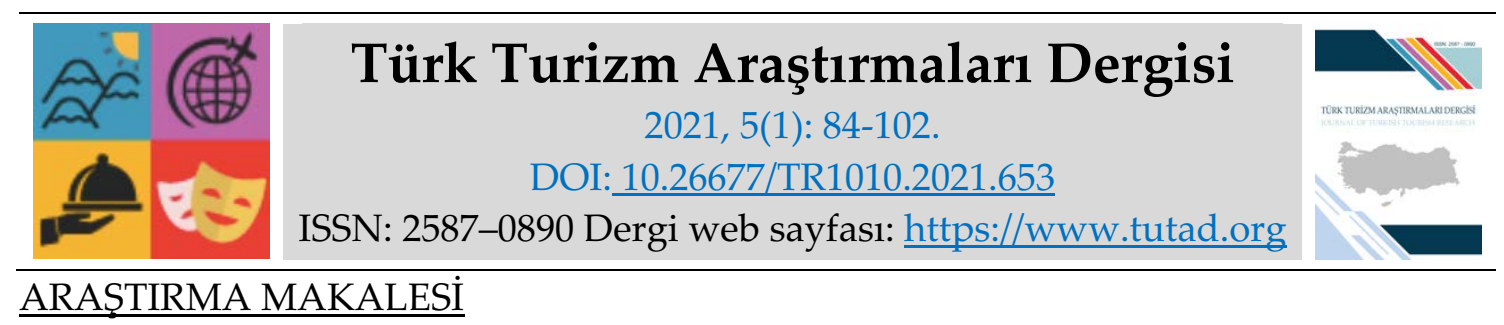

\title{
Yeni Koronavirüs (Covid-19) Günlerinde Bireylerin Yeme Tutumlarının İncelenmesi
}

Dr. Songül ÖZER, Van Yüzüncü Yll Üniversitesi, Turizm Fakültesi, Van, e-posta: songulozer@yyu.edu.tr

ORCID: https://orcid.org/0000-0003-3827-6945

Dr. Çinuçen OKAT, Van Yüzüncü Yıl Üniversitesi, Turizm Fakültesi, Van, e-posta: cinucenokat@yyu.edu.tr

ORCID: https://orcid.org/0000-0002-1335-0216

Öz

Koronavirüs salgını sürecinde bireylerin sosyal mesafeye ve hijyen kurallarına uymalarının yanında dengeli beslenmeleri sağlıklarını koruma açısından hayati bir önem kazanmıştır. Bu bağlamda koronavirüs günlerinde Türkiye'de bireylerin yeme tutumlarını incelemek bu çalışmanın temel amacını oluşturmuştur. Ayrıca bireylerin yeme tutumlarının demografik özelliklere göre farklılaşıp farklılaşmadığını belirlemek araştırmanın bir diğer amacıdır. Çalışmanın evrenini Türkiye'de ikamet eden bireyler oluşturmaktadır. Bireylerin iş yoğunluğu, zaman kısıtı ve benzeri nedenlerden dolayı örneklem alma yoluna gidilmiştir. Çalışmada kolayda örnekleme yöntemi seçilmiş olup, online anket hazırlanarak Türkiye'nin farklı illerine ulaşma noktasında kolaylık sağlanmıştır. Bu kapsamda 2020 yılının temmuz ve ağustos ayları arasında 546 geçerli ankete ulaşılmıştır. Ayrıca bu çalışmada demografik bulgular, kullanılan ölçek ile ilgili tanımlayıcı bulgular, ölçeğin doğrulayıcı faktör analizi ile farklılık analizleri için IBM SPSS versiyon 23 kullanılmıştır. Yapılan analizler sonucunda, koronavirüs günlerinde araştırmaya katılan bireylerin çoğunluğunun yeme tutumlarının duygusal yeme eğiliminde olduğu belirlenmiş ve yaşanılan yalnızlık, stres ve moral bozukluğu gibi olumsuz duygulardan dolayı aşırı yemek yeme eğilimi gösterdikleri saptanmıştır. Ayrıca koronavirüs salgını sürecinde bireylerin cinsiyetlerinin, medeni durumlarının, yaşlarının, gelir düzeylerinin ve mesleklerinin yeme tutumları üzerinde etkisi olduğu belirlenirken, eğitim durumlarının yeme tutumları üzerinde bir etkisinin olmadığı saptanmıştır.

Anahtar Kelimeler: Koronavirüs (Covid-19), Yeme Tutumu, Duygusal Yeme, Bilinçli Yeme.

Makale Gönderme Tarihi: 26.11.2020

Makale Kabul Tarihi: 02.03.2021

\section{Önerilen Atıf:}

Özer, S. ve Okat, Ç. (2021). Yeni Koronavirüs (Covid-19) Günlerinde Bireylerin Yeme Tutumlarının İncelenmesi, Türk Turizm Araştırmaları Dergisi, 5(1): 84-102.

(C) 2021 Türk Turizm Araştırmaları Dergisi. 


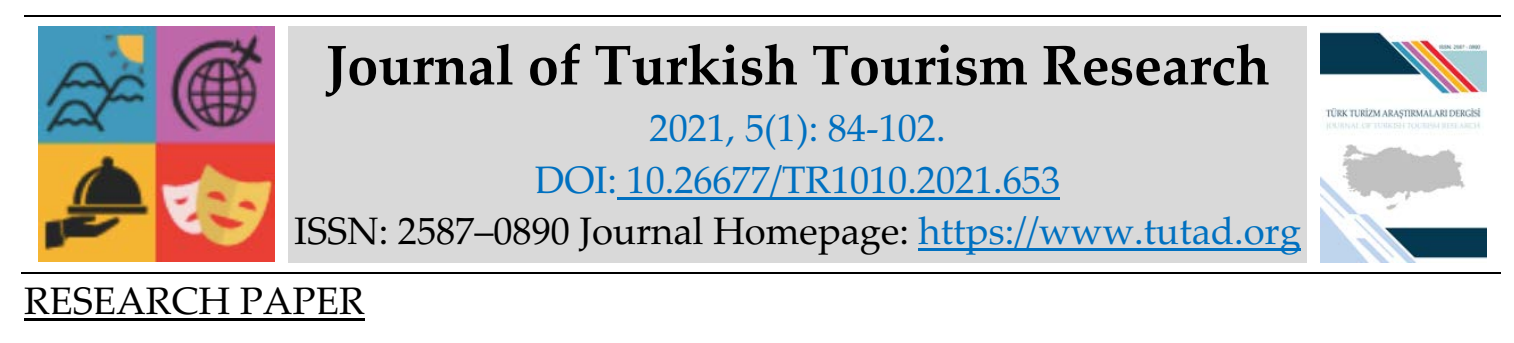

\title{
Investigation of Individuals' Eating Attitudes during the Novel Coronavirus (Covid- 19) Day
}

Dr. Songül ÖZER, Van Yüzüncü Yıl University, Faculty of Tourism, Van, e-mail: songulozer@yyu.edu.tr ORCID: https://orcid.org/0000-0003-3827-6945

Dr. Çinuçen OKAT, Van Yüzüncü Yıl University, Faculty of Tourism, Van, e-mail: cinucenokat@yyu.edu.tr ORCID: https://orcid.org/0000-0002-1335-0216

\begin{abstract}
In addition to complying with social distance and hygiene rules, balanced nutrition of individuals has gained vital importance in the field of protecting their health during the coronavirus outbreak. In this context, investigate the attitudes of individuals eating habits in Turkey has been the main purpose of this study during the coronavirus pandemic days. Also, determining whether individuals' eating attitudes differ according to demographic characteristics is another aim of the research. The study population consists of individuals to reside in Turkey. Sampling was preferred due to the individual's workload, time constraints and similar reasons. The convenience sampling method was chosen in the study, online survey is designed in order to provide ease of reaching out to the different provinces of Turkey. In this context, 546 valid surveys were reached between July and August 2020. In addition, IBM SPSS version 23 was used in this study for demographic findings, descriptive findings regarding the scale used, and confirmatory factor analysis of the scale and analysis of differences. Analyzes have shown that the eating attitudes of the majority of the individuals participating in the study during the days of coronavirus tend to eat emotionally because of negative emotions such as loneliness, stress and morale. In addition, it was determined that the gender, marital status, age, income levels and professions of individuals during the coronavirus pandemic had an effect on their eating attitudes, while educational status did not have an effect on eating attitudes.
\end{abstract}

Keywords: Coronavirus (Covid-19), Eating Attitude, Emotional Eating, Conscious Eating. Received: 26.11 .2020

Accepted: 02.03.2021

Suggested Citation:

Özer, S. and Okat, Ç. (2021). Investigation of Individuals' Eating Attitudes during the Novel Coronavirus (Covid-19) Day, Journal of Turkish Tourism Research, 5(1): 84-102.

(C) 2021 Türk Turizm Araştırmaları Dergisi. 


\section{Gíriş}

Çin'in Wuhan kentinde 2019 yılının Aralık ayında ortaya çıkan yeni koronavirüs (covid 19) salgını kısa zamanda tüm dünyayı etkisi altına alıp halk sağlığını olumsuz yönde etkilemekle kalmamış, insanların iş yaşamları, sosyal hayatları ve yaşam tarzları üzerinde önemli derecede etkileri olmuştur. Özelikle birçok ülkenin virüsün yayılmasını önlemek amacı ile getirdiği evden çalışma seçeneği, sokağa çıkma yasağı, restoranların ve eğlence yerlerinin kapatılması gibi önlemler ve kısıtlamalar, insanların daha fazla evde zaman geçirmelerine neden olmuştur. İnsanların zorunluluktan dolayı fiziksel mesafeye uymak için kendilerini soyutlamaları ve evde daha çok zaman geçirmeleri insanların günlük davranışlarını, özelliklede yeme alışkanlıklarını etkilemiştir (Di Renzo vd., 2020). Örneğin Uluslararası Gıda Bilgi Konseyi'nin (IFIC) Amerika Birleşik Devletleri'nde yaptığı 2020 Gida ve Sağlık Araştırması'na göre, Amerikaların \%85'i koronavirüs salgını nedeniyle yedikleri yiyeceklerde ve yemeklerini hazırlama yöntemlerinde değişiklik yapmışlardır. Aynı araştırmanın sonuçlarında, Amerikaların \%60'nın koronavirüs günlerinde evde daha çok yemek pişirdikleri ve \%32'si de daha fazla atıştırmalık yiyecekler tükettikleri belirtilmiştir (www.globenewswire.com).

Koronavirüs günlerinde alınan önlemler nedeni ile insanların zorunlu olarak evde kalması ve buna bağlı olarak yaşadıkları stres ve olumsuz duygular, insanların normal davranışlarından farklı davranış ve tutum içerisine girmelerine de neden olabilmektedir (Romeo-Arroyo vd., 2020). Özellikle insanların aşırı yeme ihtiyacı duymalarına neden olan faktörler arasında yaşadıkları stres ve hissettikleri olumsuz duygular gelmektedir (Evers vd., 2018). 2020 yılının Nisan ayında beş farklı kıtadaki otuz beş araştırma şirketinin katılımıyla yedi farklı dilde online olarak yapılan "Covid-19, Evde Kalma Zorunluluğunun Yeme Tutumu ve Fiziksel Aktivite Üzerindeki Etkileri" adlı çalışmanın sonucunda; bireylerin zorunlu olarak evde kaldıkları zamanlarda daha sık ara öğün yeme, ana öğün sayısını arttırma, kontrol dışı yeme eğilimi gibi sağlıksız yönde yeme alışkanlıklarının değiştiği ifade edilmiştir (Ammar vd., 2020).

Koronavirüs salgını sürecinde insanların sosyal mesafeye ve hijyen kurallarına uymalarının yanında yeterli ve dengeli beslenmeleri son derece önemlidir (Muslu ve Ersü, 2020). Bireylerin özellikle pandemi sürecinde tercih ettikleri yiyecekler ile yemek seçimi davranışları, sağlıklarını koruma açısından hayati bir önem kazanmıştır. Bu bağlamda koronavirüs günlerinde bireylerin yeme tutumlarının incelenmesi bu çalışmanın temel amacını oluşturmuştur. Araştırmanın bir diğer amacı ise pandemi sürecinde bireylerin yeme tutumlarının demografik özelliklere göre farklılaşıp farklılaşmadığını belirlemektir. Bu çalışmanın koronavirüs günlerinde bireylerin daha sağlıklı beslenmeleri konusunda yol göstermesi açısından önemli olacağı düşünülmektedir.

\section{KAVRAMSAL ÇERÇEVE}

İnsanların hayatta kalabilmesi ve yaşamlarını sürdürebilmeleri açısından temel biyolojik faaliyetlerin başında yemek yeme gelmektedir. Fakat yemek yemenin biyolojik bir ihtiyaç olmasının yanında bireylerin psikolojisi açısından da önemli olduğu kabul edilmektedir. Bireyler sinirlendiklerinde veya birine öfkelendiklerinde, kendilerini stres altında hissettiklerinde normal yeme tutumlarını değiştirerek daha fazla yemek yiyebilmekte veya hiç yemek yemeyebilmektedirler. Bu durum da biyolojik bir gereksinimden dolayı değil, bireylerin psikolojik durumlarının yeme davranışları üzerine olan etkisinden kaynaklanmaktadır (Özgen vd., 2012). Yeme davranışı; yiyecek seçimi ve güdülerini, beslenme uygulamalarını, diyet yapma ve obezite gibi yeme ve beslenme sorunlarını kapsayan geniş bir kavramdır (LaCaille, 2013). Yeme davranışı ve yemek seçimi genel olarak kültüre bağlı olarak kişisel, duygusal, sosyal ve ekonomik gibi farklı faktörlerden etkilenebilen karmaşık bir süreç olarak tanımlanmaktadır 
(Bargiota vd., 2013). Bireylerin yemek seçim kararını etkileyen ve yaygın olarak bilinen faktörler arasında sağlık, ruh hali, doğal içerik, fiyat, duygusal çekicilik, aşinalık, kilo kontrolü ve etik kaygilar da yer almaktadır (Shen vd., 2020).

Bireylerin yemek seçimi kararlarına etki eden faktörlerin etkisi ile yeme tutumları ve davranışları farklılıklar gösterebilmektedir. Yeme tarzlarına göre de farklılıklar gösteren bu tutumlar kontrolsüz yeme, bilişsel kısıtlama ve duygusal yeme olarak adlandırılmaktadır (Romeo-Arroyo vd., 2020; van Strien vd., 1986). Kontrolsüz yeme, bireylerin açlık hissettikleri ve bir dış uyarının etkisinde kaldıkları zaman yemek üzerine kontrollerini kaybetme eğilimleri olarak tanımlanmaktadır. Bilişsel kısıtlama ise, bireylerin kilolarını ve vücut şekillerini korumak için aldıkları gıdaları ve besinleri kontrol altında tutma istekleri olarak değerlendirilir. Son olarak duygusal yeme, bireylerin yalnızlık, moral bozukluğu gibi olumsuz ruh hali durumlarında aşırı yemek yeme eğilimleri olarak ifade edilmektedir (Karakuş vd., 2016).

Bireylerin karakteristik özelliklerinin yanında duygu durumları da yeme davranışlarını etkilemektedir. Örneğin salgın hastalıkların yaşandığı günlerdeki karantina yaşantısı, bireylerin duygu durumlarında bazı değişikliklere sebep olurken besleme davranışlarının değişmesine de yol açabilmektedir (Eskici, 2020). Genellikle uzun süre evde kalındığında gösterilen aşırı yeme tutumu, uzun süre evde kalmaktan dolayı hissedilen can sıkıntısından kurtulmak isteği ile ilişkilidir (Havermans vd., 2015) Ayrıca bu durumun tam tersi olarak yaşanılan olumsuz deneyimler ve stres, bireylerin daha az yeme davranışı göstermelerine neden olabilmektedir (Di Renzo vd., 2020).

Evde kalmanın zorunlu olduğu günlerde yaşanan beslenme alışkanlıklarındaki değişikler, yaşanılan duygusal durumların etkisinin yanında gıda ürünlerinin bulunabilirliğinin azalması, gıda ürünü satan yerlerin kısıtlı açılış saatlerinden dolayı yiyecek ve gıdalara sınırlı erişim imkânından da kaynaklanmaktadır (Mattioli vd., 2020). Gelecekte gıda kıtlı̆̆ı yaşanacağı endişesi, bireyleri taze yiyecekler yerine daha çok paketlenmiş ve uzun ömürlü yiyecekler satın almasına neden olmaktadır. Bireylerin bu tercihi, raf ömrü uzun olan yiyeceklerin içerdikleri tuz, şeker ve trans yağ nedeniyle sağlıklarının bozulmasına yol açmaktadır (Sivasankaran, 2010). Ayrıca kısıtlama günlerindeki stres durumu bireylerin genelde daha çabuk rahatlamasını sağlayan, stres azaltan şekerli, karbonhidrat oranları yüksek, hazırlanması kolay yiyeceklere ve besinlere yönelmelerine neden olmaktadır (Eskici, 2020; Muscogiuri vd., 2020). Örneğin koronavirüs salgınının beslenme alışkanlıkları ve yaşam tarzı değişikliği üzerine olan etkisini belirlemek amacı ile İtalya' da yürütülen çalışmanın sonucunda; salgından dolayı evde kalmanın zorunlu olduğu günlerde, ev yapımı tatlı, pizza ve ekmek gibi ürünler ile baklagiller, beyaz et ve sıcak içeceklerin tüketiminin arttı̆̆ belirtilmiş̧tir. Ayrıca bireylerin bu dönemde taze gıda, hazır paketlenmiş tatlı ve unlu mamulleri ile dışarıdan söylenen yemekleri daha az tükettikleri ifade edilmiştir (Di Renzo vd., 2020).

Salgın zamanlarında virüsün yayılmasını önlemek için yetkili kurumlarca alınan sokağa çıma yasağı sadece bireylerin gıda ve yiyecek seçimlerini değil aynı zamanda günlük normal alışkanlıklarını da etkilemektedir. Normal günlerde yemek yapmak için vakit bulamayan bireyler artık evde yemek yapmak için daha fazla zaman ayırabilmektedirler. Örneğin Suudi Arabistan' da koronavirüsün yayılmasını önlemek amacıyla sokağa çıkma yasağı uygulamasının bireylerin yaşam tarzı ve beslenme alışkanlıkları üzerine olan etkisini belirlemek amacı ile yapılan çalışma sonucunda; araştırmaya katılanların \%66'sının yemek yeme saatlerinde, \%57'sinin de günlük tükettikleri öğün sayılarında değişiklikler olduğu belirtilmiştir. Ayrıca bu değişikliğe neden olan faktörler arasında can sıkıntısı, yemek pişirmek için daha fazla zamanın olması ve gıda güvenliği endişesi olduğu ifade edilmiştir (Mumena, 2020). Tanzanya' da yapılan bir araştırma sonucunda ise, koronavirüs salgını sırasında Tanzanyalıların evde daha fazla 
yemek pişirdiğini, daha fazla meyve ve sebze tükettikleri belirtilmiştir (www.coronavirus.tas.gov.au).

2020 yılının Nisan ayında İngiltere de 2000 kişinin katılımı ile yapılan bir araştırma sonucunda, koronavirüs salgını nedeni ile kısıtlamaların başladı̆̆ı andan itibaren insanların \% 44'nün yemek pişirmekten, \% 47'sininde aileleri ve ev arkadaşları ile yemek yemekten daha fazla zevk aldı̆̆ı ifade edilmiştir. Ayrıca aynı araştırma sonucunda, insanların üçte birinden fazlasının kısıtlama günlerini yemek pişirme becerilerini geliştirmek için iyi bir fırsat olarak gördüğü belirtilmiştir ve bu oranın 16-24 yaş grubundakilerde neredeyse \% 50 oranına yaklaştı̆̆ vurgulanmıştır (Restorick, 2020). Polonya' da yapılan bir çalışmada ise, araştırmaya katılan bireylerin \% 43,5'inin koronavirüs nedeniyle sokağa çıkma yasağı günlerinde daha fazla yemek yedikleri ve \% 51,8'inin de öğünler arasında daha sık atıştırmalık ürünler tükettikleri ifade edilmiştir (Sidor ve Rzymski, 2020).

Türkiye'de ise Üsküdar Üniversitesi ile Methot Research Company'nin birlikte gerçekleştirdiği ve 18 yaş üstü üç bin kişinin katıldığg "Koronavirüslü Günlerde Hayat Araştırması" sonuçlarında; koronavirüs günlerinde özellikle 26-45 yaş grubunun yarısından fazlasının yemek yeme alışkanlığının değiştiği ve daha fazla yemek yedikleri belirtilmiştir. Ayrıca genç yaş grubunda hamurlu ve hazır gıda tüketiminin önemli derecede arttı̆̆ı ifade edilmiştir (Kam, 2020). Ayrıca Türkiye'de yürütülen ve Covid-19'a bağlı olarak bireylerin kaygı durumunun duygusal yeme davranışları üzerindeki etkisinin incelendiği ve 2 bin 276 kişinin katılımı ile gerçekleştirilen araştırmanın sonuçlarında, insanların koronavirüs salgını süresinde yeme alışkanlıklarında önemli derecede değişiklikler meydana geldiği belirtilmiştir. Özellikle olumsuz duygusal yeme davranış düzeyi yüksek olan bireylerin, koronavirüs salgının başlangıcı ile birlikte besin tüketimlerinin ve öğün sayılarının arttığı ifade edilmiştir. Ayrıca bu bireylerin fastfood ve abur cubur gibi karbonhidrat değeri yüksek olan gıdaları daha çok tükettikleri ifade edilmiştir. Meyve tüketimini daha çok gerçekleştiren bireylerde ise olumsuz duygusal yeme davranışının daha az görüldüğü tespit edilmiştir (www.alanya.edu.tr).

Yapılan literatür araştırması sonucunda, bireylerin yeme tutumlarının farklı nedenlerden dolayı değişebileceği görülmektedir. Ayrıca farklı ülkelerde yapılan araştırmaların sonuçlarında, koronavirüs salgını nedeniyle alınan önlemlerin bireylerin yeme tutumlarını etkilediği tespit edilmiştir. Daha önce yapılan çalışmaların yanında, koronavirüs günlerinde Türkiye'de bireylerin yeme tutumlarını incelemek için yapılan bu çalışmanın da literatüre katkı sağlayacağı düşünülmektedir.

\section{YÖNTEM}

$\mathrm{Bu}$ çalışmanın temel amacı koronavirüs günlerinde Türkiye'de bireylerin yeme tutumlarını incelemektir. Ayrıca bireylerin yeme tutumlarının demografik özelliklere göre farklılaşıp farklılaşmadığını belirlemek araştırmanın bir diğer amacıdır. Çalışmanın evrenini ise Türkiye'de ikamet eden bireyler oluşturmaktadır. Bireylerin iş yoğunluğu ve buna bağlı olarak yapılan çalışmaya iştirak etmeleri konusunda ortaya çıkan zaman kısıtı ve benzeri nedenlerden dolayı örneklem alma yoluna gidilmiştir. Çalışmada kolayda örnekleme yöntemi seçilmiş olup, online anket hazırlanarak Türkiye'nin farklı illerine ulaşma noktasında kolaylık sağlanmıştır. Bu kapsamda bir milyon ve üzeri evren için toplam ulaşılması gereken minimum anket sayısı Sekaran'a (2000: 95) göre 384 olup, bu çalışma için 2020 yılının Temmuz ve Ağustos ayları arasında toplanan geçerli anket sayısı ise 546' dir.

Bu çalışma kapsamında oluşturulan anket formu iki bölümden oluşmaktadır. Birinci bölümde beşli Likert ölçeğinde (1=Kesinlikle Katılmıyorum, 2=Katılmıyorum, 3=Ne Katılıyorum Ne 
Katılmıorum, 4=Katılıyorum, 5= Kesinlikle Katılıyorum) hazırlanan koronavirüs günlerinde yeme tutumu değişkenlerine yönelik ifadeler yer almaktadır. Anketin ikinci bölümünde ise katılımcıların demografik özelliklerini belirlemeye yönelik sorular yer almaktadır. Araştırmada bireylerin koronavirüs günlerinde yeme tutumlarını ölçebilmek için ilk önce Romeo-Arroyo vd., (2020) tarafından gerçekleştirilen çalışmada yer alan ifadelerden araştırmanın amacına uygun olanlar seçilmiş, sonra da alanında uzman kişilerinde görüşleri alınarak bu ifadelere yeni ifadeler eklenmiştir. Sonuçta 19 ifade ile bireylerin koronavirüs günlerindeki yeme tutumları ölçülmüştür.

Anket formunun oluşturulmasında yabancı kaynaktan uyarlanan ifadelerin anlaşılırlığı, İngiliz Dili ve Edebiyatı alanında uzman öğretim üyesi tarafından kontrol edilmiştir. Ayrıca araştırma konusunda daha önce çalışmalar yapmış ve alanında uzman üç öğretim üyesi tarafından anket formunun tamamı kontrol edilmiştir. Araştırma kapsamında toplanan veriler uygun istatistiki yöntemler kullanılarak analiz edilmiştir. Bu bağlamda demografik bulgular, kullanılan ölçek ile ilgili tanımlayıcı bulgular, ölçeğin doğrulayıcı faktör analizi ile farklılık analizleri için IBM SPSS version 23 kullanılmıştır.

Bu çalışmada kullanılan ölçek ve veriler, Van Yüzüncü Yıl Üniversitesi Sosyal ve Beşeri Bilimler Yayın Etik Kurul Başkanlığı tarafından etik kurallara ve İlkelere uygun bulunmuştur (Kurul Karar Tarihi ve Sayısı: 16/11/2020-2020/13-11).

\section{BULGULAR}

\section{Araştırmanın Örneklem Gurubunun Demografik Özelliklerine İlişkin Bulgular}

Çalışmanın bu bölümünde araştırmaya katılan bireylerin demografik özelliklerine göre dağılımı çerçevesinde; cinsiyet, medeni durum, yaş, eğitim durumu, meslek ve gelir durumu yer almaktadır. Ayrıca bireylerin çocuk sahibi olup olmadığı ve koronavirüs salgını nedeni ile alınan önlemler çerçevesinde sokağa çıkma yasağı günlerinde işe gitmek zorunda olup olmadıklarını gösteren bulgular da yer almaktadır. Bireylerin demografik özelliklerine yönelik bulgular Tablo 1'de gösterilmektedir.

Tablo 1 incelendiğinde örneklemin \%59'u kadın, \%41'i erkektir. Medeni durumuna göre ise \%61,4'ü evli, \%38,6'sı bekârdır. Buna göre araştırmaya katılanların çoğunluğunun kadın ve büyük bir bölümün evli olduğunu söylemek mümkündür. Ayrıca katılımcıların \%54,6's1 çocuk sahibi iken \%45,4'ü çocuk sahibi değildir. Yaşlarına göre araştırmaya katıların dağılımlarına baktığımızda \%7,9'u 20 yaşından küçük, \%42,1'i 21 ile 35 yaş arasında, \%39,7'si 36 ile 50 yaş arasında ve $\% 8,2$ 'si ise 51 ile 64 yaş arasında olup \%2,1'i de 65 yaşından büyüktür. Bu duruma göre araştırmaya katılanların yarısının 35 yaşından küçük ve yarısının ise 35 yaşından büyük olduğu söylenebilir.

Katılımcların eğitim durumu incelediğimizde ise büyük çoğunluğunun \%46,3'ü lisans ve $\% 22,9^{\prime}$ u lisansüstü mezunu olduğunu görmek mümkündür. Katılımcıların çoğunluğunun \%32,4'ü özel sektörde ve \%28'i kamu sektöründe çalıştığ1 söylenebilir. Araştırmaya katılanların aylık ortalama gelir düzeyine baktığımızda ise çoğunluğunun $(\% 28,8)$ 4000-5999 TL gelir grubunda olduğu ve bunu takiben 2324 TL ve altı gelir durumu olan grubunda $(\% 25,1)$ ikinci sırada olduğu ifade edilebilir. Ayrıca katılımcıların büyük bir çoğunluğu $(\% 76,7)$ koronavirüs salgını nedeni ile alınan önlemler çerçevesinde sokağa çıkma yasağ günlerinde işe gitmek zorunda olmadıklarını ifade etmişlerdir. 
Tablo 1: Katılımcıların Demografik Özellikler Açısından Dağılımı

\begin{tabular}{|l|c|c|l|c|c|}
\hline & (n) & $\mathbf{( \% )}$ & & (n) & (\%) \\
\hline Cinsiyet & & & Meslek & & \\
\hline Kadın & 322 & 59,0 & Ev Hanımı & 45 & 8,2 \\
\hline Erkek & 224 & 41,0 & Emekli & 25 & 4,6 \\
\hline Medeni Durum & & & Öğrenci & 86 & 15,8 \\
\hline Evli & 325 & 61,4 & $\begin{array}{l}\text { Özel Sektör } \\
\text { Çalışanı }\end{array}$ & 177 & 32,4 \\
\hline Bekâr & 211 & 38,6 & Esnaf & 24 & 4,4 \\
\hline $\begin{array}{l}\text { Çocuğunuz Var } \\
\text { mı? }\end{array}$ & & & Kamu Personeli & 153 & 28,0 \\
\hline Evet & 298 & 54,6 & Çalışmiyor & 36 & 6,6 \\
\hline Hayır & 248 & 45,4 & $\begin{array}{l}\text { İşe Gitme } \\
\text { Zorunluluğu }\end{array}$ & & \\
\hline Yaşınız & & & Evet & 127 & 23,3 \\
\hline 20 ve altı & 43 & 7,9 & Hayır & 419 & 76,7 \\
\hline 21-35 arası & 230 & 42,1 & Aylık Gelir & & \\
\hline 36-50 arası & 217 & 39,7 & 2324 TL ve Altı & 137 & 25,1 \\
\hline $51-64$ arası & 45 & 8,2 & 2325-3999 TL & 101 & 18,5 \\
\hline 65 ve üstü & 11 & 2,1 & $4000-5999$ TL & 157 & 28,8 \\
\hline Eğitim Durumu & & & $6000-7999$ TL & 62 & 11,4 \\
\hline İlköğretim & 24 & 4,4 & 8000 TL ve Üstü & 89 & 16,3 \\
\hline Lise & 77 & 14,1 & & & \\
\hline Ön Lisans & 67 & 12,3 & & & \\
\hline Lisans & 253 & 46,3 & & & \\
\hline Lisans Üstü & 125 & 22,9 & & & \\
\hline
\end{tabular}

\section{Araştırmanın Ölçeğinin Güvenilirlik Analizi Bulguları}

Çalışmada, sosyal bilimlerde, ölçeklerin güvenilirliğini test etmek amacıyla Cronbach Alpha iç tutarlılık değerinin hesaplanması yöntemi kullanılmıştır. Cronbach Alpha, 0 ile 1 arasında bir değer almakta ve değerin 1'e yakın olması güvenilirliğin arttığını göstermektedir (Meriç ve Güllüce, 2017; Yazıcıoğlu ve Erdoğan, 2011). Buna göre söz konusu değer; ,40'1n altı güvenilir değil; , $40<\alpha<$,60 düşük güvenilirlikte; ,60 $<\alpha<, 80$ oldukça güvenilir; , $80<\alpha<1,00$ yüksek derecede güvenilir şeklinde yorumlanmaktadır (Devellis, 2014). Çalışmada yer alan Yeme Tutumu ölçeğinin ve alt boyutlarının Cronbach alfa katsayıları Tablo 2'de yer almaktadır. 
Tablo 2. Güvenilirlik Analizi

\begin{tabular}{|l|c|c|}
\hline Ölçek ve Alt Boyutları & Ölçek Cronbach Alfa & İfade Sayısı \\
\hline Genel Yeme Tutumu &, $\mathbf{8 6 8}$ & $\mathbf{1 9}$ \\
\hline Duygusal Yeme &, 849 & 12 \\
\hline Bilinçli Yeme &, 733 & 7 \\
\hline
\end{tabular}

Tablo 2' de yer alan sonuçlar değerlendirildiğinde yukarıda verilen bilgiler çerçevesinde ölçeğin tamamında ve alt boyutlarında güvenilirliğinin yeterli düzeyde olduğu söylenebilir.

\section{Araştırmanın Ölçeğinin Faktör Analizi Bulguları}

Faktör analizi, birbiriyle ilişkili çok sayıda değişkeni bir araya getirerek az sayıda kavramsal olarak anlamlı yeni değişkenler (faktörler, boyutlar) bulmayı, keşfetmeyi amaçlayan çok değişkenli bir istatistiktir (Ural ve Kılıç, 2006: 281; Büyüköztürk, 2002: 472). Faktör analizi, açımlayıcı ve doğrulayıcı olmak üzere iki temel gruba ayrılmaktadır. Açımlayıcı faktör analizinde, değişkenler arasındaki ilişkilerden hareketle faktör bulma ve teori üretme işlemi gerçekleştirilirken; doğrulayıcı faktör analizinde değişkenler arasında daha önce saptanan ilişkiye dair bir hipotezin test edilmesi söz konusudur (Büyüköztürk, 2002). Bu çalışmada daha önce geliştirilmiş yeme tutumu ölçeği için öncelikle verilerin normal dağılıp dağılmadığını test etmek amacıyla normallik analizleri yapılmıştır. Elde edilen verilerin normal dağılım gösterip göstermediği çoğunlukla Kolmogorov Smirnow ve Shapiro Wilk testi kullanılarak belirlenmeye çalışılmaktadır. Bu analizlerin sonuçlarında ifadelere ait anlamlılık düzeyi 0,05'den küçük çıkması yani anlamlı olması, verilerin normal dağılım göstermediği anlamına gelmektedir. Ancak Tabachnick ve Fidell'e (2001) göre çarpıklık (skewness) ve basıklık (kurtosis) değerlerinin $+1,5$ ile $-1,5$ arasında bir değer alması, verilerin normal dağılım gösterdiği anlamına gelmektedir. Elde edilen verilere ait çarpıklık ve basıklık değerlerine bakıldığında söz konusu değerlerin bu aralıkta yer aldığı görülmektedir. Bu doğrultuda verilerin normal dağılım gösterdiğini söylemek mümkündür.

Ayrıca bu çalışmada faktör analizi yapılmadan önce verilerin faktör analizi için uygun olup olmadığını gösteren Kaiser-Meyer-Olkin (KMO) katsayısına bakılmıştır. KMO katsayısı, analizde kullanılacak veri setinin ve örneklem büyüklüğünün yeterli olup olmadığını ortaya koyan bir testtir. Yapılan testlerin sonucunda KMO değeri ,882 olarak bulunmuştur. Büyükyılmaz'a (2007) göre KMO değerinin ,70'den büyük olması mevcut veriler ile faktör analizi yapılabileceğini göstermektedir. Yeme Tutumu ölçeğinin açılanan toplam varyans yüzdesi 56,788 olarak hesaplanmış olup ölçekteki ifadelerin faktör yükleri Varimax dik döndürme yöntemi ile tespit edilmiştir. 
Tablo 3. Faktör Analizi Sonuçları

\begin{tabular}{|c|c|c|}
\hline & 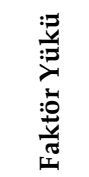 & 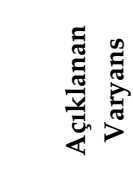 \\
\hline 1. Duygusal Yeme & & 31,450 \\
\hline Koronavirüs günlerinde eskisinden daha sık acıktığımı fark ettim. & 709 & \\
\hline $\begin{array}{l}\text { Koronavirüs günlerinde ruh halim iyi değil ve bu yemek tercihimi } \\
\text { etkiyor }\end{array}$ &, 544 & \\
\hline $\begin{array}{l}\text { Koronavirüs günlerinde eskisinden daha sık yemek yiyorum } \\
\text { (günde daha fazla öğün ) }\end{array}$ & 788 & \\
\hline $\begin{array}{l}\text { Koronavirüs günlerinde genel olarak, eskisinden daha fazla yemek } \\
\text { yediğimi düşünüyorum (miktar olarak) }\end{array}$ & ,789 & \\
\hline $\begin{array}{l}\text { Koronavirüs günlerinde öğünler arasında daha fazla atıştırmalık } \\
\text { yiyorum }\end{array}$ & 753 & \\
\hline $\begin{array}{l}\text { Koronavirüs günlerinde işlenmiş ürün tüketimim arttı (endüstriyel } \\
\text { pişmiş ürünler, hazır yemekler vb.) }\end{array}$ & 439 & \\
\hline $\begin{array}{l}\text { Koronavirüs günlerinde çerez, cips, şeker gibi atıştırmalık ürünler } \\
\text { tüketimim arttı. }\end{array}$ & 671 & \\
\hline $\begin{array}{l}\text { Koronavirüs günlerinde daha fazla kahve, çay, enerji içeceği gibi } \\
\text { uyarıcı içecek tüketiyorum. }\end{array}$ &, 580 & \\
\hline $\begin{array}{l}\text { Koronavirüs günlerinde genellikle televizyon, tablet, bilgisayar vb. } \\
\text { izlerken yemek yiyorum }\end{array}$ & 648 & \\
\hline $\begin{array}{l}\text { Koronavirüs günlerinde yemek pişirmek için daha fazla zaman } \\
\text { harciyorum }\end{array}$ &, 598 & \\
\hline Koronavirüs günlerinde her gün daha sık yemek pişiriyorum &, 596 & \\
\hline $\begin{array}{l}\text { Koronavirüs günlerinde özellikle tatlı ve pasta gibi ürünleri } \\
\text { yapmak için mutfakta daha çok zaman geçiriyorum }\end{array}$ &, 543 & \\
\hline 2.Bilinçli Yeme & & 25,338 \\
\hline $\begin{array}{l}\text { Koronavirüs günlerinde yiyeceklerimin sağlıklı olmalarına özen } \\
\text { gösteriyorum }\end{array}$ & 420 & \\
\hline $\begin{array}{l}\text { Koronavirüs günlerinde sağllğım için eskisinden daha fazla sanal } \\
\text { marketler üzerinden gıda ürünü sipariş ediyorum }\end{array}$ & ,343 & \\
\hline $\begin{array}{l}\text { Koronavirüs günlerinde besin takviyesi tüketimim arttı (vitaminler, } \\
\text { mineraller, vb.) }\end{array}$ & ,371 & \\
\hline $\begin{array}{l}\text { Koronavirüs günlerinde sağlıklı yemekler pişirmek için internetten } \\
\text { faydalanyorum }\end{array}$ & 743 & \\
\hline $\begin{array}{l}\text { Koronavirüs günlerinde sebze meyve gibi sağlıklı ürünler } \\
\text { tüketimim arttı. }\end{array}$ & ,525 & \\
\hline $\begin{array}{l}\text { Koronavirüs günlerinde sağlıklı beslenmek için eskisinden daha } \\
\text { fazla tarif okuyup, şefleri ve yemek programlarını takip ediyorum }\end{array}$ & 753 & \\
\hline $\begin{array}{l}\text { Koronavirüs günlerinde sağlıklı beslenmek için çevremdeki } \\
\text { insanlardan yeni yemek tarifleri alıyorum }\end{array}$ & 753 & \\
\hline
\end{tabular}


Yukarıda yer alan Tablo $3^{\prime}$ te ölçekte kullanılan ifadelerin faktör analizi sonrasında ölçeğin alt boyutlarını oluşturan ifadelerin faktör yükleri yer almaktadır. Faktör analizleri sırasında ifadeler değerlendirilirken çoğunlukla ,30'un (Büyüköztürk, 2005) alt sınır olarak alınabileceği ifade edilmekte ve bu değerin üzerindeki maddelerin ölçekte kalması uygun görülmektedir. Örneklem büyüklüğü arttıkça bu değerin aşağı çekildiği görülmektedir. Akdağ, (2011: 26) ,30 yük değeri için örneklem büyüklüğünün en az 350 olması gerektiğini belirtmektedir. Bu çalışmada örneklem büyüklüğü 546 olup gerekli koşulları sağladığı görülmektedir. Yeme tutumu ölçeğine yönelik yapılan faktör analizi sonuçlarına göre iki boyut elde dilmiştir. Literatür araştırmasında elde edilen bilgiler kapsamında ve maddelerin içerikleri dikkate alınarak bu iki boyut; duygusal yeme ve bilinçli yeme boyutu olarak adlandırılmıştır. Ayrıca yeme tutumu ölçeğinin birinci boyutu olan duygusal yeme 12 ifadeden oluşmakta ve açılanan varyans oranının \%31,450 olduğu görülmektedir. İkinci boyut olan bilinçli yeme tutumu ise 7 ifadeden oluşmakta ve açılanan toplam varyans oranı $\% 25,338$ olarak hesaplanmıştır.

\section{Farklılık Analizleri Bulguları}

Çalışma T-Testleri ve Tek Yönlü Anova analizleri yapılmadan önce ön koşul olarak kabul edilen varyansların homojen dağılıp dağılmadıkları test edilmiştir. Bu kapsamında yapılan T-Testleri ve Tek Yönlü Anova analizleri sonucunda bütün varyansların homojen dağıldığı sonucuna varılmış olup Sig. (P) değerleri bu doğrultuda dikkate alınmıştır.

Tablo 4. Cinsiyete Göre T-Testi Sonuçları

\begin{tabular}{|c|c|c|c|c|c|c|}
\hline Boyutlar & Cinsiyet & $N$ & $X$ & SS & $F$ & Sig. $(P)$ \\
\hline \multirow{2}{*}{$\begin{array}{l}\text { Genel Yeme } \\
\text { Tutumu }\end{array}$} & Kadin & 322 & 3,1548 & 62785, & \multirow{2}{*}{,369 } & \multirow[t]{2}{*}{, 000 } \\
\hline & Erkek & 224 & 2,9366 & 68175 & & \\
\hline \multirow[t]{2}{*}{ Duygusal Yeme } & Kadın & 322 & 3,0921 & 74545, & \multirow{2}{*}{,319 } & \multirow[t]{2}{*}{,000 } \\
\hline & Erkek & 224 & 2,8475 & ,74346 & & \\
\hline \multirow[t]{2}{*}{ Bilinçli Yeme } & Kadın & 322 & 3,2622 & ,70340 & \multirow{2}{*}{,966 } & \multirow[t]{2}{*}{,006 } \\
\hline & Erkek & 224 & 3,0893 & ,75535 & & \\
\hline
\end{tabular}

İstatistiksel anlamlılık düzeyi: ,05

Tablo 4 incelendiğinde katılımcıların cinsiyetleri ile genel yeme tutumu $(p=, 000)$ ile alt boyutları olan duygusal yeme $(p=, 000)$ ve bilinçli yeme boyutlarının $(p=, 006)$ anlamlı bir şekilde farklılaştığ 1 görülmektedir. Ayrıca genel yeme tutumu ile duygusal yeme ve bilinçli yeme alt boyutlarında kadınların ortalamalarının (X değerinin), erkeklerin ortalamalarından daha büyük olduğu görülmektedir. Diğer bir ifade ile kadınlardaki yeme tutumunun erkeklere oranla daha yüksek olduğu söylenebilir. 
Tablo 5. Medeni Duruma Göre T-Testi Sonuçları

\begin{tabular}{|c|c|c|c|c|c|c|}
\hline Boyutlar & $\begin{array}{l}\text { Medeni } \\
\text { Durum }\end{array}$ & $N$ & $X$ & SS & $F$ & Sig. $(P)$ \\
\hline \multirow{2}{*}{$\begin{array}{l}\text { Genel Yeme } \\
\text { Tutumu }\end{array}$} & Evli & 335 & 3,0247 & ,66312 & \multirow{2}{*}{,057 } & \multirow[t]{2}{*}{,070 } \\
\hline & Bekâr & 211 & 3,1297 & 64800 & & \\
\hline \multirow[t]{2}{*}{ Duygusal Yeme } & Evli & 335 & 2,9318 & ,74680 & \multirow{2}{*}{,297 } & \multirow[t]{2}{*}{ 019 } \\
\hline & Bekâr & 211 & 3,0869 & , 75642 & & \\
\hline \multirow[t]{2}{*}{ Bilinçli Yeme } & Evli & 335 & 3,1838 & ,73280 & \multirow{2}{*}{, 044} & \multirow[t]{2}{*}{,763 } \\
\hline & Bekâr & 211 & 3,2031 & ,72572 & & \\
\hline
\end{tabular}

İstatistiksel anlamlılık düzeyi: ,05

Tablo 5 incelendiğinde ise katılımcıların medeni durumları ile genel yeme tutumu $(p=, 070)$ ile alt boyutu olan bilinçli yeme boyutunda $(p=, 763)$ anlamlı bir farklılaşma olmadığı görülmektedir Katılımcların medeni durumları ile duygusal yeme boyutunda ise anlamlı bir farklılaşma olduğu saptanmıştır $(p=, 019)$. Ayrıca duygusal yeme boyutunda bekârların ortalamalarının (X değerinin), evlilerin ortalamalarından daha büyük olduğu görülmektedir. Diğer bir ifade ile bekâr katılımcılardaki duygusal yeme tutumunun evli katılımcılara oranla daha yüksek olduğu söylenebilir.

Tablo 6: Çocuk Durumuna Göre T-Testi Sonuçları (Çocuğunuz var mı?)

\begin{tabular}{|c|c|c|c|c|c|c|}
\hline Boyutlar & $\begin{array}{c}\text { Çocuk } \\
\text { Durumu }\end{array}$ & $N$ & $X$ & $S S$ & $F$ & Sig. $(P)$ \\
\hline \multirow{2}{*}{$\begin{array}{l}\text { Genel Yeme } \\
\text { Tutumu }\end{array}$} & Evet & 298 & 2,9799 & 66960 & \multirow{2}{*}{ 703 } & \multirow[t]{2}{*}{,001 } \\
\hline & Hayır & 248 & 3,1679 & ,63158 & & \\
\hline \multirow[t]{2}{*}{ Duygusal Yeme } & Evet & 298 & 2,8901 & ,73274 & \multirow{2}{*}{,146 } & \multirow[t]{2}{*}{,001 } \\
\hline & Hayır & 248 & 3,1139 & 76169 & & \\
\hline \multirow[t]{2}{*}{ Bilinçli Yeme } & Evet & 298 & 3,1337 & ,74225 & \multirow{2}{*}{,383 } & \multirow[t]{2}{*}{, 043 } \\
\hline & Hayır & 248 & 3,2604 & ,70913 & & \\
\hline
\end{tabular}

İstatistiksel anlamlılık düzeyi: ,05

Tablo 6'da çocuğu olan ve olmayan katılımcılar ile genel yeme tutumu $(\mathrm{p}=, 001)$ ile alt boyutları olan duygusal yeme $(p=, 001)$ ve bilinçli yeme boyutlarının $(p=, 043)$ anlamlı bir şekilde farklılaştığ görülmektedir. Ayrıca genel yeme tutumu, duygusal yeme ve bilinçli yeme boyutunda çocuğu olmayan katılımcıların (X değerinin), çocuğu olan katılımcıların ortalamalarından daha büyük olduğu görülmektedir. Sonuç olarak çocuğu olmayan katılımcıların yeme tutumlarının, çocuğu olan katılımcılara oranla daha yüksek olduğu söylenebilir.

Tablo 7' de Covid'19 döneminde işe gitmek zorunda olan ve olmayan katılımcılar ile genel yeme tutumu $(p=, 026)$ ile alt boyut olan bilinçli yeme boyutunun $(p=, 026)$ anlamlı bir şekilde farklılaştı̆̆ 1 görülmektedir. Ancak Covid'19 döneminde işe gitmek zorunda olan ve olmayan katılımcılarda duygusal yeme boyutunun $(p=, 067)$ anlamlı bir şekilde farklılaşmadığı sonucuna varılmıştır. Ayrıca genel yeme tutumu ve bilinçli yeme boyutunda işe gitmek zorunda olmayan katılımcların (X değerinin), işe gitmek zorunda olan katılımcıların ortalamalarından daha büyük olduğu görülmektedir. Diğer bir ifade ile genel yemek yeme tutumunda ve bilinçli yeme 
tutumunda işe gitmek zorunda olmayan katılımcıların yeme tutumlarının daha yüksek olduğu sonucuna varılmıştır.

Tablo 7. İşe Gitme Durumuna Göre T-Testi Sonuçları

\begin{tabular}{|c|c|c|c|c|c|c|}
\hline Boyutlar & $\begin{array}{l}\text { Isse Gitme } \\
\text { Durumu }\end{array}$ & $N$ & $X$ & $S S$ & $F$ & Sig. $(P)$ \\
\hline \multirow{2}{*}{$\begin{array}{l}\text { Genel Yeme } \\
\text { Tutumu }\end{array}$} & Evet & 127 & 2,9511 & 71057 & \multirow{2}{*}{1,381} & \multirow[t]{2}{*}{,026 } \\
\hline & Hayır & 419 & 3,0999 & 63904 & & \\
\hline \multirow[t]{2}{*}{ Duygusal Yeme } & Evet & 127 & 2,8845 & ,75724 & \multirow{2}{*}{,022 } & \multirow[t]{2}{*}{,067 } \\
\hline & Hayır & 419 & 3,0243 & ,75043 & & \\
\hline \multirow[t]{2}{*}{ Bilinçli Yeme } & Evet & 127 & 3,0652 & ,77241 & \multirow{2}{*}{1,081} & \multirow[t]{2}{*}{,026 } \\
\hline & Hayır & 419 & 3,2295 & 71251 & & \\
\hline
\end{tabular}

İstatistiksel anlamlılık düzeyi: ,05

Tablo 8. Yaşa Göre Anova Testi

\begin{tabular}{|c|c|c|c|c|c|c|}
\hline Boyutlar & Gruplar & $N$ & $X$ & SS & $F$ & Sig. $(P)$ \\
\hline \multirow{5}{*}{$\begin{array}{l}\text { Genel Yeme } \\
\text { Tutumu }\end{array}$} & 20 ve alt1 & 43 & 3,1995 & ,58038 & \multirow{5}{*}{6,536} & \multirow{5}{*}{,000 } \\
\hline & $\begin{array}{l}21-35 \\
\text { aras1 }\end{array}$ & 230 & 3,1783 & 63717 & & \\
\hline & $\begin{array}{l}36-50 \\
\text { aras1 }\end{array}$ & 217 & 2,9956 & 67396 & & \\
\hline & $\begin{array}{l}51-64 \\
\text { aras1 }\end{array}$ & 45 & 2,8398 & 63634 & & \\
\hline & 65 ve üstü & 11 & 2,4737 &, 50262 & & \\
\hline \multirow{5}{*}{ Duygusal Yeme } & 20 ve alt1 & 43 & 3,2074 & ,72269 & \multirow{5}{*}{6,284} & \multirow{5}{*}{,000 } \\
\hline & $\begin{array}{l}21-35 \\
\text { aras1 }\end{array}$ & 230 & 3,1130 & 72679 & & \\
\hline & $\begin{array}{l}36-50 \\
\text { aras1 }\end{array}$ & 217 & 2,9059 & 77931 & & \\
\hline & $\begin{array}{l}51-64 \\
\text { aras1 }\end{array}$ & 45 & 2,7130 & 65293 & & \\
\hline & 65 ve üstü & 11 & 2,4470 &, 54425 & & \\
\hline \multirow{5}{*}{ Bilinçli Yeme } & 20 ve altı & 43 & 3,1860 & 60169 & \multirow{5}{*}{4,034} & \multirow{5}{*}{,003 } \\
\hline & $\begin{array}{l}21-35 \\
\text { aras1 }\end{array}$ & 230 & 3,2901 & 73457 & & \\
\hline & $\begin{array}{l}36-50 \\
\text { aras1 }\end{array}$ & 217 & 3,1494 & 71107 & & \\
\hline & $\begin{array}{l}51-64 \\
\text { aras1 }\end{array}$ & 45 & 3,0571 & 80663 & & \\
\hline & 65 ve üstü & 11 & 2,5195 & ,70645 & & \\
\hline
\end{tabular}

İstatistiksel anlamlılık düzeyi: ,05 
Tablo 8 incelendiğinde katılımcıların yaş grupları ile genel yeme tutumu $(p=, 000)$ ve alt boyutları olan duygusal yeme $(p=, 000)$ ile bilinçli yeme boyutlarının $(p=, 003)$ anlamlı bir şekilde farklılaştığ görülmektedir. Yaş gruplarına göre farklılıklar incelenecek olursa; Genel yeme tutumu ile duygusal yeme boyutunda 21 yaş ve altı grupta farklılaşmanın da fazla olduğu (X değeri) görülmektedir. Bilinçli yeme boyutunda ise 21-35 yaş aralığında farklılaşmanın diğer yaş gruplarına oranla daha fazla olduğu görülmektedir. Sonuç olarak Covid'19 sürecinde 35 ve altı yaş grubunda yemek yeme tutumunun diğer yaş gruplarına oranla daha çok farklılaştığ 1 söylenebilir.

Tablo 9. Eğitim Durumuna Göre Anova Testi

\begin{tabular}{|c|c|c|c|c|c|c|}
\hline Boyutlar & Gruplar & $N$ & $X$ & SS & $F$ & Sig. $(P)$ \\
\hline \multirow{5}{*}{$\begin{array}{l}\text { Genel Yeme } \\
\text { Tutumu }\end{array}$} & İlköğretim & 24 & 3,0504 & ,49555 & \multirow{5}{*}{,816 } & \multirow{5}{*}{, 515} \\
\hline & Lise & 77 & 3,1422 & 64285 & & \\
\hline & Ön lisans & 67 & 2,9678 & 68690 & & \\
\hline & Lisans & 253 & 3,0882 & 64824 & & \\
\hline & Lisansüstü & 125 & 3,0265 & 70119 & & \\
\hline \multirow{5}{*}{ Duygusal Yeme } & İlköğretim & 24 & 3,0347 & 63031 & \multirow{5}{*}{,777 } & \multirow{5}{*}{,540 } \\
\hline & Lise & 77 & 3,1017 & 76288 & & \\
\hline & Ön lisans & 67 & 2,9428 & 78993 & & \\
\hline & Lisans & 253 & 3,0016 & 74950 & & \\
\hline & Lisansüstü & 125 & 2,9220 & ,76022 & & \\
\hline \multirow{5}{*}{ Bilinçli Yeme } & İlköğretim & 24 & 3,0774 & ,44974 & \multirow{5}{*}{1,449} & \multirow{5}{*}{ 217 } \\
\hline & Lise & 77 & 3,2115 & 68064 & & \\
\hline & Ön lisans & 67 & 3,0107 & 76863 & & \\
\hline & Lisans & 253 & 3,2366 & 72615 & & \\
\hline & Lisansüstü & 125 & 3,2057 & ,77875 & & \\
\hline
\end{tabular}

İstatistiksel anlamlılık düzeyi: ,05

Tablo 9'da katılımcıların eğitim durumlarına göre yemek yeme tutumlarında farklılaşma olup olmadığına yönelik Anova Testi sonuçları yer almaktadır. Analiz sonucunda $\mathrm{p}=, 05$ anlamlılık düzeyinde katılımcıların eğitim durumuna göre yemek yeme tutumlarında anlamlı bir farklılaşma olmadığı sonucuna varılmıştır.

Tablo 10 incelendiğinde ise katılımcıların gelir düzeyleri genel yeme tutumu $(p=, 029)$ ve alt boyutu olan duygusal yeme boyutunun $(\mathrm{p}=, 006)$ anlamlı bir şekilde farklılaştı̆̆ görülmektedir. Ancak gelir düzeyi ile bilinçli yeme boyutu arasında anlamlı bir farklılaşmaya rastlanmamıştır. Gelir gruplarına göre farklılıkları inceleyecek olursak; genel yeme tutumu ile duygusal yeme boyutunda en yüksek farklılaşmanın (X değerleri) düşük gelir grubu olan 2324 TL ve altı grupta olduğu görülmektedir. 
Tablo 10. Gelir Düzeyine Göre Anova Testi

\begin{tabular}{|c|c|c|c|c|c|c|}
\hline Boyutlar & Gruplar & $N$ & $X$ & SS & $F$ & Sig. (P) \\
\hline \multirow{5}{*}{$\begin{array}{l}\text { Genel Yeme } \\
\text { Tutumu }\end{array}$} & 2324 TL ve alt1 & 137 & 3,1829 & ,59395 & \multirow{5}{*}{2,730} & \multirow{5}{*}{, 029} \\
\hline & 2325-3999 TL & 101 & 3,1443 & 61791 & & \\
\hline & $4000-5999 \mathrm{TL}$ & 157 & 3,0127 & 67331 & & \\
\hline & $6000-7999 \mathrm{TL}$ & 62 & 2,9830 & 71341 & & \\
\hline & 8000 TL ve üstü & 89 & 2,9444 & ,70605 & & \\
\hline \multirow{5}{*}{$\begin{array}{l}\text { Duygusal } \\
\text { Yeme }\end{array}$} & 2324 TL ve altı & 137 & 3,1411 & 70404 & \multirow{5}{*}{3,703} & \multirow{5}{*}{,006 } \\
\hline & 2325-3999 TL & 101 & 3,1007 & 74034 & & \\
\hline & $4000-5999 \mathrm{TL}$ & 157 & 2,9342 & ,77625 & & \\
\hline & $6000-7999 \mathrm{TL}$ & 62 & 2,8804 & 78386 & & \\
\hline & 8000 TL ve üstü & 89 & 2,8174 & 73543 & & \\
\hline \multirow[t]{5}{*}{ Bilinçli Yeme } & 2324 TL ve altı & 137 & 3,2544 & 64466 & \multirow{5}{*}{, 500} & \multirow{5}{*}{ 736 } \\
\hline & $2325-3999 \mathrm{TL}$ & 101 & 3,2192 & 69710 & & \\
\hline & $4000-5999 \mathrm{TL}$ & 157 & 3,1474 & 75288 & & \\
\hline & $6000-7999 \mathrm{TL}$ & 62 & 3,1590 & 78762 & & \\
\hline & 8000 TL ve üstü & 89 & 3,1621 & 80875 & & \\
\hline
\end{tabular}

İstatistiksel anlamlılık düzeyi: ,05

Tablo 11. Mesleğe Göre Anova Testi

\begin{tabular}{|c|c|c|c|c|c|c|}
\hline Boyutlar & Gruplar & $N$ & $X$ & SS & $F$ & Sig. $(P)$ \\
\hline \multirow{7}{*}{$\begin{array}{l}\text { Genel } \\
\text { Yeme } \\
\text { Tutumu }\end{array}$} & Ev hanimı & 45 & 3,1135 & 63237 & \multirow{7}{*}{4,251} & \multirow{7}{*}{,000 } \\
\hline & Emekli & 25 & 2,6211 & ,65438 & & \\
\hline & Öğrenci & 86 & 3,2326 & 60061 & & \\
\hline & Özel sektör çalışanı & 177 & 3,0740 & 65991 & & \\
\hline & Esnaf & 24 & 2,6996 & ,62785 & & \\
\hline & Kamu personeli & 153 & 3,0740 & 66592 & & \\
\hline & Çalışmiyorum & 36 & 3,0775 & ,63564 & & \\
\hline \multirow{7}{*}{$\begin{array}{l}\text { Duygusal } \\
\text { Yeme }\end{array}$} & Ev hanımı & 45 & 3,0148 & ,75027 & \multirow{7}{*}{2,542} & \multirow{7}{*}{,000 } \\
\hline & Emekli & 25 & 2,5733 & ,69610 & & \\
\hline & Öğrenci & 86 & 3,2374 & 69810 & & \\
\hline & Özel sektör çalışanı & 177 & 3,0033 & ,75175 & & \\
\hline & Esnaf & 24 & 2,5243 & ,65038 & & \\
\hline & Kamu personeli & 153 & 2,9755 & ,77013 & & \\
\hline & Çalışmiyorum & 36 & 2,9907 & ,70676 & & \\
\hline \multirow{7}{*}{$\begin{array}{l}\text { Bilinçli } \\
\text { Yeme }\end{array}$} & Ev hanımı & 45 & 3,2825 & 63267 & \multirow{7}{*}{2,471} & \multirow{7}{*}{,023 } \\
\hline & Emekli & 25 & 2,7029 & ,76256 & & \\
\hline & Öğrenci & 86 & 3,2243 & 70244 & & \\
\hline & Özel sektör çalışanı & 177 & 3,1953 & 75371 & & \\
\hline & Esnaf & 24 & 3,0000 & 72232 & & \\
\hline & Kamu personeli & 153 & 3,2428 & 72457 & & \\
\hline & Çalışmıyorum & 36 & 3,2262 & 69599 & & \\
\hline
\end{tabular}

İstatistiksel anlamlılık düzeyi: ,05 
Tablo 11'de katılımciların meslek grupları ile genel yeme tutumu $(p=, 000)$ ve alt boyutları olan duygusal yeme $(p=, 000)$ ile bilinçli yeme boyutlarının $(p=, 023)$ anlamlı bir şekilde farklılaştığ görülmektedir. Meslek gruplarına göre farklılıklar incelenecek olursa; genel yeme tutumu $(x=3,2326)$ ile duygusal yeme boyutunda $(x=3,2374)$ en yüksek farklılaşmanın öğrenci gruplarında olduğu görülmektedir. Bilinçli yeme tutumunda ise ev hanımlarında $(x=3,2825)$ farklılaşmanın diğer meslek gruplarına oranla daha fazla olduğu görülmektedir.

\section{SONUÇ ve ÖNERILER}

Bu çalışmada koronavirüs günlerinde Türkiye'de bireylerin yeme tutumları belirlenmeye çalışılmıştır. Ayrıca bu Covid-19 sürecinde bireylerin yeme tutumlarının demografik özelliklere göre farklılaşıp farklılaşmadığı incelenmiştir. Bu anlamda bu çalışma, koronavirüs salgını günlerinde bireylerin nasıl beslendiklerine dair önemli bulgular ortaya koymakta ve literatüre çeşitli alanlarda katkı sağlamaktadır.

Araştırmanın amacı kapsamında öncelikle koronavirüs günlerinde bireylerin genel yeme tutumları incelenmiştir. Bu amaç doğrultusunda geliştirilen yeme tutumu ölçeğinin geçerliliğini ve güvenilirliğini analiz edebilmek için yapılan açıklayıcı faktör analizi sonucuna göre, yeme tutumu ölçeği iki boyuttan oluşmuştur. Duygusal Yeme olarak isimlendirilen birinci boyutun açılanan varyans oranının (\%31,450), Bilinçli Yeme olarak adlandırılan ikinci boyutun açılanan toplam varyans oranının ise $(\% 25,338)$ olduğu belirlenmiştir. Bu bağlamda koronavirüs günlerinde bireylerin genel yeme tutumlarının duygusal yeme eğiliminde olduğunu söylemek mümkündür. Diğer bir ifade ile bireylerin pandemi süresinde yaşadıkları yalnızlık, stres ve moral bozukluğu gibi olumsuz duygulardan dolayı aşırı yemek yeme eğilimi gösterdikleri söylenebilir. $\mathrm{Bu}$ durum literatürdeki bulgularla aynı doğrultudadır (Ammar vd., 2020; www.globenewswire.com; Mumena, 2020; Sidor ve Rzymski, 2020).

Aynı zamanda koronavirüs günlerinde bireylerin yeme tutumlarını belirlemek amacı ile geliştirilen ölçeğe uygulanan açılayıcı faktör analiz sonuçlarında; Duygusal Yeme boyutunun en güçlü göstergesi "Koronavirüs günlerinde genel olarak, eskisinden daha fazla yemek yediğimi düşünüyorum (miktar olarak)" ile "Koronavirüs günlerinde eskisinden daha sık yemek yiyorum (günde daha fazla öğün )" maddeleri olduğu tespit edilmiştir. Bu duruma neden olarak sokağa çıkma yasağı günlerinde bireylerin zorunluluktan dolayı veya sağlıklarını korumak için kendi istekleri ile evde daha çok zaman geçirmeleri gösterilebilir. Bu sonuç, Mumena (2020)'nın Suuidi Arabistan' da yaptığı çalışma ile Ammar ve arkadaşlarının (2020) beş farklı kıtada gerçekleştirdiği çalışmanın sonuçları ile örtüşmektedir. Bilinçli Yeme boyutunda ise "Koronavirüs günlerinde sağlıklı beslenmek için eskisinden daha fazla tarif okuyup, şefleri ve yemek programlarını takip ediyorum" ile "Koronavirüs günlerinde sağlıklı beslenmek için çevremdeki insanlardan yeni yemek tarifleri alıyorum" maddelerinin en güçlü gösterge olduğu söylenebilir. Bunun nedeni olarak, bireylerin evde kaldığı günlerde sağlıklı beslenebilmek için kendilerini geliştirmek istemeleri ve bunu gerçekleştirirken de yalnızlıklarını bir nebze azaltabilmek adına sosyalleşme ihtiyacı içerisinde olmaları gösterilebilir. Bu sonuçlar İtalya'da Di Renzo ve arkadaşları (2020) tarafından gerçekleştirilen "Koran virüs Salgınının Beslenme Alışkanlıkları ve Yaşam Tarzı Değişikliği Üzerine Olan Etkisi" adlı araştırmanın bazı sonuçları ile benzerlik göstermektedir. İtalya' da gerçekleştirilen bu çalışmada salgından dolayı evde kalmanın zorunlu olduğu günlerde bireylerin sağlıklı beslenmek için organik meyve ve sebzelere olan ilgisinin arttığı belirtilmiştir.

Araştırmanın diğer önemli çıktıları ise, koronavirüs salgını sürecinde bireylerin demografik özelliklerinin yeme tutumları üzerine olan etkilerinin belirlenmesidir. Elde edilen bulgular doğrultusunda koronavirüs günlerinde bireylerin cinsiyetlerinin yeme tutumları üzerinde 
etkisinin olduğu sonucu elde ediliştir. Ayrıca bu süreçte daha çok kadınların yeme tutumlarının etkilendiği saptanmıştır. Bunun nedeni olarak kadınların evde daha çok zaman geçirmek zorunda olmalarının yanında kadınlarda olumsuz duygulara tepki olarak daha çok atıştırmalık ürünler yeme durumunun gözlemlenmesi gösterilebilir (Levitan ve Davis, 2010). Araştırmanın bir diğer önemli bulgusu ise bekârların Covid-19 salgını sürecinde duygusal yeme tutumlarının daha çok etkilendiği yönündedir. Bunun da bekârların kendileri yemek pişirmek yerine hazır yemek ve atıştırmalık ürünleri daha çok tercih etmeleri söylenebilir.

Araştırma sonuçlarına göre, Covid-19 salgını sürecinde çocuğu olmayan bireylerin yeme tutumlarının çocuk sahibi bireylere göre daha çok etkilendiği şeklindedir. Bunun nedeni olarak çocuklu ailelerin yeme alışkanlıklarının değiştirilmesi, çocuklarından dolayı daha zor olması gösterilebilir. Araştırmanın bir diğer sonucu ise sokağa çıkma yasağı günlerinde işe gitmek zorunda olmayan katılımcıların daha çok bilinçli yeme tutumu sergiledikleri yönündedir. Bunun nedeni olarak yasak sürecinde çalışmak zorunda olamayan kesimin daha çok kamu personeli ve bir nebze refah düzeyi yüksek bireylerin olması olabilir. Araştırma sonucunda elde edilen önemli bulgulardan bir tanesi ise, Covid-19 sürecinde 21 yaş altı grubun daha fazla duygusal yeme tutumu sergilemeleridir. Buna neden olarak genç nüfusun atıştırmalık ürünleri daha çok tercih etmeleri ve sağlıklı beslenmeye daha az önem vermeleri gösterilebilir. Bu sonuç Türkiye'de ise Üsküdar Üniversitesi ile Methot Research Company'nin birlikte gerçekleştirdiği (Kam, 2020) araştırmanın sonucu ile örtüşmektedir.

Araştırmanın ilgi çeken sonuçlarından bir tanesi ise, Covid-19 salgını sürecinde bireylerin eğitim düzeylerinin yeme tutumlarını etkilemediği bulgusudur. Bunun nedeni olarak günümüzde hayatta olan insanların, bu derecede tüm dünyayı etkisi altına alan bir salgın ile ilk kez karşılaşmış olması ve bu yaşanan sürecin her eğitim düzeyindeki bireyler için bir ilk olması söylenebilir. Araştırmanın bir diğer sonucu ise, salgın sürecinde en çok duygusal yeme tutumu sergileyenlerin düşük gelir düzeyine sahip bireyler olduğudur. Bunun temel nedeni olarak Covid'19 sürecinin beraberinde getirmiş olduğu işsizlik ve buna bağlı olarak gelirin daha da düşmesi sonucu bireylerin yaşadığı stres gösterilebilir. Araştırmanın son bulgusu ise, Covid-19 sürecinde öğrencilerin diğer meslek gruplarına göre daha fazla duygusal yeme tutumu sergilemesi ve ev hanımlarının daha bilinçli yeme tutumu içerisinde olmalarıdır. Bunun nedeni olarak öğrencilerin daha özgürce dışarıda zaman geçirirken birden eve kapanmak zorunda kalmaları sonucu kendilerini yemeğe vermeleri olabilirken, ev hanımlarının ise sağlıklı ev yemekleri hazırlamaya daha yatkın olmaları gösterilebilir.

Araştırma kapsamında gerçekleştirilen analiz sonuçlarında elde edilen bulgular literatürdeki çalışmalar ile birlikte değerlendirildiğinde, koronavirüs günlerinde bireylerin daha sağlıklı ve bilinçli beslenmesi için şu şekilde öneriler getirilebilir. Bireyler özellikle sokağa çıkma yasağının uygulandığı zamanlarda can sıkıntılarının önüne geçmek için kendilerine yeni hobiler kazanabilirler. Böylelikle bir nebze istem dışı yeme isteklerini ve öğün sayılarını kontrol altında tutabilirler. Sağlıklı beslenme konusunda hem sosyal medyada hem de farklı iletişim araçlarında yayımlanan bilgilere ulaşabilirler. Eğer bu konuda sağlıklı bilgiye ulaşmakta zorluk çekiyorlarsa aile büyüklerinin, eş, dost ve akrabalarının bilgilerinden ve tecrübelerinden yararlanabilirler. Ayrıca bu dönemde bireyleri sağlıklı beslenme konusunda bilinçlendirmek için, Sağlık Bakanlığı gibi devlet kurumları ile bu konuda uzman sivil toplum kuruluşlarına ve medya kurumlarına büyük sorumluluk düşmektedir. Bu kurumlar, bireylerin daha sağlıklı ve bilinçli beslenmesi için projeler gerçekleştirebilir ve uzman kişilerin tavsiyelerini sürekli olarak halkla paylaşabilir.

Bu çalışmanın bazı kısıtlıkları bulunmaktadır. Bu çalışma zaman kısıtlılığı nedeni kısa sürede sınırlı bir örneklem üzerinde yapılmıştır. Hiç şüphesiz örneklem hacmi genişletilip daha fazla kişiden veri toplanması durumunda daha genel ve kapsamlı sonuçlara ulaşılabilir. Bu bağlamda 
ileride bu konu hakkında araştırma yapacak araştırmacılara daha geniş zaman diliminde ve örneklem üzerinde çalışmaların yapılması önerilir.

\section{KAYNAKÇA}

Alanya.edu.tr (2020). Çarpıcı Tespit: Covid-19 Yeme Alışkanlığımızı Değiştirdi [Online] https://www.alanya.edu.tr/news/carpici-tespit-covid-19-yeme-aliskanligimizi-degistirdi (Erişim tarihi: 29.092020).

Akdağ, M. (2011). SPSS'de İstatistiksel Analizler. Malatya: İnönü Üniversitesi Web Yönetim Paneli.

Ammar, A., Brach, M., Trabelsi, K., Chtourou, H., Boukhris, O., Masmoudi, L. and Müller, P. (2020). Effects of COVID-19 Home Confinement on Eating Behaviour and Physical Activity: Results of the ECLB-COVID19, International Online Survey. Nutrients, 12(6): 1583.

Bargiota, A., Delizona, M., Tsitouras, A. and Koukoulis, G. N. (2013). Eating Habits and Factors Affecting Food Choice of Adolescents Living in Rural Areas, Hormones, 12(2): 246-253.

Büyüköztürk, Ş. (2002). Faktör Analizi: Temel Kavramlar ve Ölçek Geliştirmede Kullanımı, Kuram ve Uygulamada Ĕ̈itim Yönetimi Dergisi, 8(4): 470-483.

Büyüköztürk, Ş. (2005). Sosyal Bilimler için Veri Analizi El Kitabı. (5. Baskı). Ankara: Cantekin Matbaası.

Büyükyılmaz, O. (2007). Işsletmelerde Yabancllaşmanın Sosyo-psikolojik Etkileri ve Türkiye Taşkömürü Kurumunda Bir Uygulama, Yayınlanmamış Yüksek Lisans Tezi, Karaelmas Üniversitesi, Zonguldak.

Devellis, F. (2014). Ölçek Geliştirme. (3. Basım). İstanbul: Nobel Yayın Dağıtım.

Di Renzo, L., Gualtieri, P., Pivari, F., Soldati, L., Attinà, A., Cinelli, G. and Esposito, E. (2020). Eating Habits and Lifestyle Changes During COVID-19 Lockdown: An Italian Survey. Journal of Translational Medicine, 18(1): 1-15.

Eskici, G. (2020). Covid-19 Pandemisi: Karantina İçin Beslenme Önerileri. Anadolu Kliniği Tıp Bilimleri Dergisi, 25(Special Issue on COVID 19): 124-129.

Evers, C., Dingemans, A., Junghans, A. F. and Boevé, A. (2018). Feeling Bad or Feeling Good, Does Emotion Affect Your Consumption of Food? A Meta-Analysis of The Experimental Evidence. Neuroscience \& Biobehavioral Reviews, 92, 195-208.

Havermans, R. C., Vancleef, L., Kalamatianos, A. and Nederkoorn, C. (2015). Eating and Inflicting Pain Out of Boredom, Appetite, 85, 52-57.

https://coronavirus.tas.gov.au/facts/Stay-Healthy-Stay-Connected/how-covid-19-has-changedour-eating-habit (Erişim Tarihi, 28.09.2020).

https://www.globenewswire.com/news-release/2020/06/10/2046323/0/en/COVID-19-Pandemic Transforms-the-Way-We-Shop-Eat-and-Think-About-Food-According-to-IFIC-s-2020-FoodHealth-Survey.html (Erişim Tarihi: 05.09.2020).

Kam, G. (2020). Koronavirüs Günlerinde Yemek Alışkanlığımız Değişti! Hamurlu ve Hazır Gıda Tüketiyoruz. [Online] https://www.milliyet.com.tr/gundem/koronavirus-gunlerinde-yemekaliskanligimiz-degisti-hamurlu-ve-hazir-gida-tuketiyoruz-6209037 (Erişim Tarihi: 29.09.2020). 
Karakuş, S. Ş., Yıldırım, H. ve Büyüköztürk, Ş. (2016). Üç Faktörlü Yeme Ölçeğinin Türk Kültürüne Uyarlanması: Geçerlik ve Güvenirlik Çalışması. TAF Preventive Medicine Bulletin, 15(3): 229-237.

LaCaille L. (2013) Eating Behavior. In: Gellman M.D., Turner J.R. (eds) Encyclopedia of Behavioral Medicine (pp 641-642 New York: Springer.

Levitan, R. D. and Davis, C. (2010). Emotions and Eating Behaviour: Implications for The Current Obesity Epidemic. University of Toronto Quarterly, 79(2): 783-799.

Mattioli, A. V., Sciomer, S., Cocchi, C., Maffei, S. and Gallina, S. (2020). Quarantine During COVID-19 Outbreak: Changes in Diet and Physical Activity Increase the Risk of Cardiovascular Disease. Nutrition, Metabolism and Cardiovascular Diseases, 30(9): 1409-1417.

Meriç S. ve Güllüce A.Ç. (2017). Değişime Direnç ve Örgütsel Sessizlik Bağlamında Yenilikçilik: TRA1 ve TRB2 Bölgesi Turizm İşletmelerine Yönelik Bir Araştırma. İstanbul: Lambert Academic Puplishing.

Mumena, W. A. (2020) Impact of COVID-19 Curfew on Eating Habits, Food Intake, and Weight According to Food Security Status in Saudi Arabia: A Retrospective Study. Progress in Nutrition, $22(3): 1-9$

Muscogiuri, G., Barrea, L., Savastano, S. and Colao, A. (2020). Nutritional Recommendations for Covid-19 Quarantine. European Journal of Clinical Nutrition, 74, 850-851.

Muslu, M. ve Ersü, D. Ö. (2020). Yeni Koronavirüs (SARS-CoV-2/COVID-19) Pandemisi Sırasında Beslenme Tedavisi ve Önemi. Beslenme ve Diyet Dergisi, 48(1): 73-82.

Özgen, L., Kinaci, B. ve Arli, M. (2012). Ergenlerin Yeme Tutum ve Davranışları. Journal of Faculty of Educational Sciences, 45(1): 229-247.

Restorick T. (2020) How has Covid-19 Changed Our Eating Habits [Online] https://www.hubbub.org.uk/blog/how-has-covid-19-changed-our-eating-habits (Erişim Tarihi: 28.09.2020).

Romeo-Arroyo, E., Mora, M. and Vázquez-Araújo, L. (2020). Consumer Behavior in Confinement Times: Food Choice and Cooking Attitudes in Spain, International Journal of Gastronomy and Food Science, 21, 1-5

Sekaran U. (2000). Research Methods for Business: A Skill Building Approach, Third Edition. USA: John Wiley \& Sons.

Shen, W., Long, L. M., Shih, C. H. and Ludy, M. J. (2020). A Humanities-Based Explanation for The Effects of Emotional Eating and Perceived Stress on Food Choice Motives During The COVID-19 Pandemic. Nutrients, 12(9): 1-18.

Sidor, A. and Rzymski, P. (2020). Dietary Choices and Habits during COVID-19 Lockdown: Experience from Poland. Nutrients, 12 (6): 1-13.

Sivasankaran, S. (2010). The Cardio-Protective Diet. The Indian Journal of Medical Research, 132(5): 608-616.

Tabachnick, B. G. and Fidell, L. S. (2001). Using Multivariate Statistics. Boston: Pearson.

Ural, A. ve Kılıç, İ. (2006). Bilimsel Araştırma Süreci ve SPSS ile Veri Analizi. Ankara: Detay Yayıncilik.

Van Strien, T., Frijters, J. E., Bergers, G. P. and Defares, P. B. (1986). The Dutch Eating Behavior Questionnaire (DEBQ) for Assessment of Restrained, Emotional, and External Eating Behavior. International Journal of Eating Disorders, 5(2): 295-315. 
Yazıcıoğlu, Y. ve Erdoğan, S. (2011). SPSS Uygulamalı Bilimsel Araştırma Yöntemleri. Ankara: Detay Yayıncilık. 